ESJ Humanities

\title{
The Effect of Data-Driven Learning of Grammar on Georgian EFL University Students' Grammar Achievement
}

\author{
Nino Tsulaia, PhD Candidate \\ International Black Sea University, Tbilisi, Georgia
}

Doi:10.19044/esj.2021.v17n33p168

Submitted: 19 August 2021

Accepted: 13 September 2021

Published: 30 September 2021
Copyright 2021 Author(s)

Under Creative Commons BY-NC-ND

4.0 OPEN ACCESS

Cite As:

Tsulaia N. (2021). The Effect of Data-Driven Learning of Grammar on Georgian EFL University Students' Grammar Achievement. European Scientific Journal, ESJ, 17 (33), 168. https://doi.org/10.19044/esj.2021.v17n33p168

\section{Abstract}

The purpose of this study is to investigate the effect of Data-Driven Learning of grammar on Georgian English as a Foreign Language (EFL) University students' grammar achievement. The study used a quasiexperimental research design with a quantitative approach. The sample of the research was 44 Georgian EFL students of Sokhumi State University, divided into experimental and control groups with 22 students in each. The experimental group was instructed English grammar using the Data-Driven Learning method and the control group was taught by conventional, explicit grammar teaching approach. The result of the paired-samples T-test showed that there was a significant difference in the scores for the control group $(\mathrm{M}=62.13, \mathrm{SD}=14.46)$ and experimental group $(\mathrm{M}=1.5, \mathrm{SD}=0.58)$ conditions; $\mathrm{t}=8.3, \mathrm{df}=3$, significance $\mathrm{p}=0.003<0.05$. Thus, the difference between control and experimental group achievements was statistically valuable, Data-Driven group students achieved significantly higher results than the traditional teaching group students. A questionnaire was applied to evaluate experimental group students' perceptions of the Data-Driven Learning method. The results showed that students felt positive about the DDL method. Based on students' achievements and evaluation of the method, it can be inferred that Data-Driven Grammar Learning is an effective grammar instruction method. It builds a student-centered learning environment with improved classroom interaction, enhanced autonomous learning, and increased student engagement. It offers real-life language exploration possibilities and a skills-oriented grammar 
teaching process.

Keywords: Data-Driven Learning, EFL grammar, student-centered learning, active learning

\section{Introduction}

In the Georgian higher education EFL (English as a Foreign Language) context, grammar instruction is generally carried out through the deductive approach. The deductive approach to grammar teaching constitutes a teachercentered method, the teacher transmits all information to students - provides grammar rules and explanations, and then, the students apply the rules to specific examples. In this way, the learners are passive recipients of the knowledge. Technological advances of the past decades originated a new field - corpus linguistics. The development of corpus linguistics emerged new trends in language education. Corpus-based teaching creates new opportunities for language teaching including grammar and offers transformation of traditional teaching into active, student-centered, constructivist learning.

\section{Literature Review:}

According to Reppen (2010), a corpus is "a large, principled collection of naturally occurring texts (written or spoken) stored electronically (p. 23). Corpus linguistics denotes corpus-based language studies. It emerged in the 1950s. The potential and benefits of corpora for language education have been soon recognized and gained increasing attention among scholars and teachers. Applying a corpus in language instruction started in the 1980s. The exploitation of a corpus for language teaching is referred to as Data-Driven Learning. The concept of Data-Driven Learning (DDL) was coined by Johns (1990).

Corpus has two kinds of application in the foreign language classroom: indirect application by the learners - the teacher designs corpus-based materials for students and the students detect the language patterns in these resources, or direct application - the students interact with corpus software where they investigate the language. Thus, there is paper-based or computerbased/hands-on Data-Driven Learning (Brown, 2017; Elsherbini \& Ali 2017). In the DDL activities, learners have the role of researchers, they examine the data on a specific language feature, categorize the data, make a generalization based on the evidence and draw conclusions. Corpora make it available to do both quantitative and qualitative analysis of language patterns. Learners can get a frequency of occurrence of the target feature in the corpus as well as investigate its use in authentic contexts (O'Keeffe, McCarthy \& Carter, 2007). 
Learners can observe and analyze grammatical structures as well as lexicogrammatical patterns.

Chujo and Oghigian (2008) developed a Data-Driven Grammar Learning method, shown in figure 1.

Figure 1 : The Data-Driven Grammar Learning method

$$
\begin{gathered}
\text { Hypothesis development by the learners through } \\
\text { paper-based DDL tasks }
\end{gathered}
$$

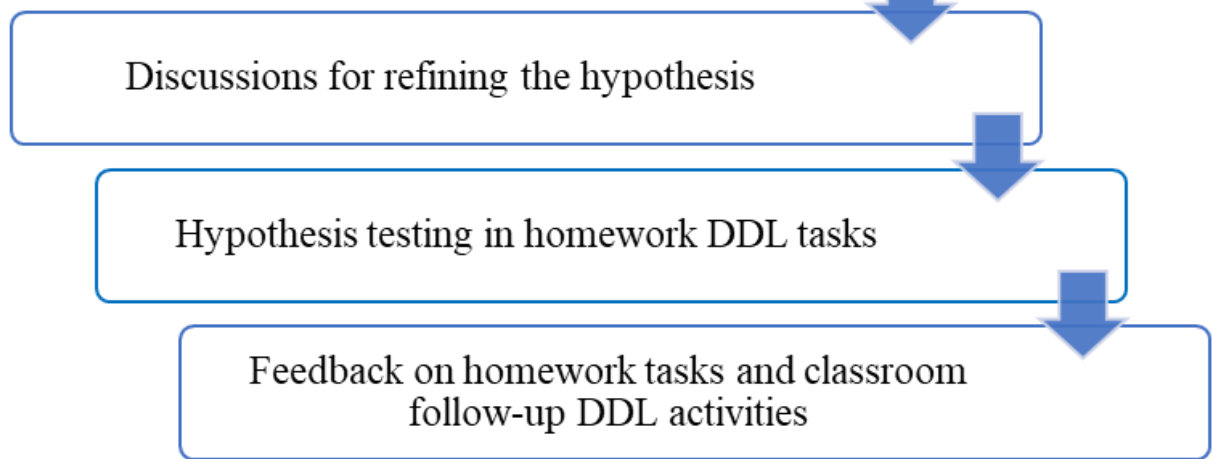

Source: Chujo and Oghigian, 2008.

In the first step, students are provided with paper-based DDL tasks. Students in pairs or groups observe the presented concordance lines on a particular grammar point and develop a hypothesis on the formation and use of this target grammar point. In the second step, the teacher gives some explanations or clarifications that allow students to improve or confirm their hypotheses. In the third step, students test the hypothesis in homework DDL tasks prepared by the teacher, and in the final step, the teacher provides feedback on completed homework tasks and some practice continues through classroom activities.

Data-Driven Learning has many advantages. First of all, through corpora students can explore the language in authentic contexts. Students become familiar with real-language examples.

The Data-Driven Learning method induces active learning in class (Chambers, 2010; Lee 2011). Students carry out investigations on language features. Data-Driven Learning is a constructivist teaching method (Boulton \& Cobb, 2017; Lili, 2015). It focuses on building knowledge by the learners rather than passively transmitting the knowledge to them. Students "work independently or collaboratively to observe, analyze, and interpret patterns of language use" (Huang, 2008, p. 21). DDL activities foster interaction in class among the students and the students and the instructor as well (Meunier, 2002).

The Data-Driven Learning method transforms the roles of the teacher as well as students. In the established student-centered environment, students 
perform as researchers, whereas the teacher acts as a facilitator (Huang, 2018; Kazuko, 2014). Data-Driven Learning encourages students' autonomy (Sah, 2015; Zhang \& Liu, 2014).

The Data-Driven Learning method facilitates the development of higher-order thinking skills of students. Numerous cognitive skills are involved in Data-Driven Learning, e.g. "predicting, observing, noticing, thinking, reasoning, analyzing, interpreting, reflecting, exploring, making inferences (inductively or deductively), focusing, guessing, comparing, differentiating, theorizing, hypothesizing, and verifying" (O'Sullivan, 2007, p. 277).

Data-Driven Learning is often considered to be appropriate for advanced language learners. Though, there are scholars who claim DDL relevance to all levels of language proficiency. For example, Al-Gamal and Ali (2019) assert that the corpus-based teaching method is beneficial for all levels of students' language proficiency. Moreover, there are studies (e.g., Boulton, 2008; Chujo, Utiyama \& Miura, 2006; Takahashi \& Fujiwara, 2016; Yunus, 2014) that proved the effectiveness of Data-Driven learning on elementary language level students as well.

\section{Research Methodology: \\ The design of the study}

This study used a quasi-experimental research design. A quantitative research method was applied in it. The research sought to investigate the following research questions: 1) How effective is Data-Driven Learning of grammar on EFL University students' grammar achievement? 2) What are the attitudes of the experimental group students toward the Data-Driven Grammar Learning method?

The population of this research was the first-year students of the faculty of Education Sciences of Sokhumi State University, Tbilisi, the capital of Georgia. They were taking English as a Foreign Language as a compulsory course in their majors. There were four groups of freshmen students, with a total number of 100 students, at the faculty of Education Sciences in the academic year 2020-2021. Out of four groups, two groups, with 22 students in each, were selected as a sample. The purposive sampling technique was used in the selection of these two groups - students of both groups were similar in English ability level. One group (consisting of 16 females and 6 males) was assigned as an experimental group, the other one (consisting of 15 females and 7 males) as a control group. So, the total sample of this research was 44 EFL students. Their ages ranged from 18-20 years. Their proficiency level of English was B1. 


\section{Treatment}

The treatment was given to both, experimental and control groups. The experimental (DDL) group was instructed grammar through the four-step Data-Driven Grammar Learning paradigm developed by Chujo and Oghigian (2008). Data-Driven Learning tasks provided by the teacher at the first step of learning included original concordance lines on a particular grammar point in KWIC (Key Words in Context) format taken from Corpora at CQPweb of Lancaster University (Hardie, 2012), in particular British National Corpus (XML Edition), Brown Family (extended) and BNC sampler. The concordance lines were followed by the leading questions students needed to focus on when forming hypotheses. Data-Driven Learning tasks developed by the teacher for homework or classroom follow-up activities at the third and fourth steps of the paradigm were of different types: multiple-choice, gapfilling, Matching, True/False, error correction, transformation, close/openended, etc. Primarily, in all DDL tasks, original concordance lines were maintained, occasionally they were adopted to students' language proficiency level.

The control (traditional teaching) group was an explicit instruction group, learning grammar deductively. The teacher provided rules and explanations on a specific target grammar point and then the students applied those rules to different instances. LASER B1 (Mann \& Taylore-Knowles, 2013) was used to teach target grammar points to the control group.

The treatment lasted 8 weeks, 16 contact hours in total. Grammar points taught to the experimental and the control group were identical. These were: countable and uncountable nouns, comparatives and superlatives, modals, time clauses, and relative clauses.

\section{The research tools}

Two research tools - tests (pre and post-tests) and a questionnaire were developed to achieve the objectives of the study. Ordinary, non-DDL grammar tests were created for research: the pre-test aimed to evaluate students' grammatical knowledge before treatment, the post intended to measure students' achievements after treatment. The questionnaire was designed to evaluate students' attitudes towards the experimental method. The tests comprised 50 questions on the target grammar points in multiple-choice format. The questionnaire included close-ended questions. There were 10 items in the questionnaire. They followed the five-point Likert scale from 1 (strongly disagree) to 5 (strongly agree).

For ensuring the validation of the pre and post-tests and the questionnaire, their content validity, and face validity were checked. Content and face validity were assessed by 3 qualified specialists in the fields of English Philology and Education Sciences. For verifying the reliability of the 
research tools, the tests and the questionnaire were piloted within a group of 10 students. Their reliability was measured with test-retest correlation. For the pre-test, Pearson correlation was 0.997 and the significance was $\mathrm{p}=0.000<0.01$; and for the post-test, the correlation was 0.998 and the significance was $\mathrm{p}=0.000<0.01$. As for the questionnaire, the Pearson correlation was 0.934 and the significance was $\mathrm{p}=0.000<0.01$. The piloting results of the tools demonstrated that in all three cases, Pearson correlation was higher than 0.08 and the significance was below 0.01 which means that in each case there was a strong correlation between the two results, the results were statistically significant and the tools (pre-test, post-test, and questionnaire) were reliable.

\section{The procedures of gathering and analyzing data}

The data was gathered by using the pre-test, post-test, and questionnaire. The pre-test was administered to the experimental and control group students before treatment to evaluate the students' grammatical knowledge before treatment was given. The post-test was administered to the students of both groups after treatment to find out what achievements the students obtained. In addition to the post-test, the questionnaire was given to the experimental group students to evaluate their perceptions of the DataDriven Learning method. The results of the tests and the questionnaire were prepared for analysis.

SPSS 22.0 statistics program was used for analyzing the data of the research. Through the program, the mean, median, mode(s), and standard deviation of the groups' results were calculated. To see how significant the differences between groups were t-test was applied. The results of the questionnaire were also analyzed using the SPSS program.

\section{Results and Discussions:}

Students' test results and descriptive analyses of the results are shown in Table 1 and Table 2. 
Table 1 : Control group

\begin{tabular}{|c|c|c|}
\hline Student & Pre-test & Post-test \\
\hline Student 1 & 73 & 82 \\
\hline Student 2 & 52 & 68 \\
\hline Student 3 & 54 & 70 \\
\hline Student 4 & 46 & 56 \\
\hline Student 5 & 61 & 78 \\
\hline Student 6 & 36 & 58 \\
\hline Student 7 & 56 & 75 \\
\hline Student 8 & 62 & 80 \\
\hline Student 9 & 52 & 63 \\
\hline Student 10 & 42 & 63 \\
\hline Student 11 & 51 & 70 \\
\hline Student 12 & 53 & 78 \\
\hline Student 13 & 75 & 86 \\
\hline Student 14 & 45 & 62 \\
\hline Student 15 & 47 & 69 \\
\hline Student 16 & 43 & 61 \\
\hline Student 17 & 45 & 67 \\
\hline Student 18 & 43 & 62 \\
\hline Student 19 & 37 & 52 \\
\hline Student 20 & 34 & 59 \\
\hline Student 21 & 55 & 71 \\
\hline Student 22 & 45 & 63 \\
\hline Mean & 50.32 & 67.86 \\
\hline Median & 54.5 & 69 \\
\hline Mode(s) & 45 & 63 \\
\hline $\begin{array}{l}\text { St. } \\
\text { Deviation }\end{array}$ & 10.68 & 9.02 \\
\hline
\end{tabular}

Source: Developed by the author.

Table 2 : Experimental group

\begin{tabular}{|l|l|l|}
\hline Student & Pre-test & Post-test \\
\hline Student 1 & 63 & 89 \\
\hline Student 2 & 45 & 69 \\
\hline Student 3 & 51 & 74 \\
\hline Student 4 & 77 & 98 \\
\hline Student 5 & 41 & 78 \\
\hline Student 6 & 53 & 85 \\
\hline Student 7 & 35 & 67 \\
\hline Student 8 & 44 & 75 \\
\hline Student 9 & 74 & 97 \\
\hline Student 10 & 46 & 82 \\
\hline Student 11 & 53 & 79 \\
\hline Student 12 & 37 & 71 \\
\hline Student 13 & 44 & 79 \\
\hline Student 14 & 52 & 86 \\
\hline Student 15 & 55 & 84 \\
\hline Student 16 & 57 & 84 \\
\hline Student 17 & 61 & 91 \\
\hline Student 18 & 39 & 67 \\
\hline Student 19 & 54 & 80 \\
\hline Student 20 & 40 & 75 \\
\hline Student 21 & 42 & 72 \\
\hline Student 22 & 46 & 77 \\
\hline Mean & 50.41 & 79.95 \\
\hline Median & 56 & 82.5 \\
\hline Mode(s) & 44,46 and & $67,75,79$ \\
& 53 & and 84 \\
\hline St. & 11.11 & 8.77 \\
Deviation & & \\
\hline Sd by the author. & \\
\hline
\end{tabular}

No significant difference was found between the mean scores of the experimental and control groups in the pre-test. The experimental group received a slightly higher result than the control group $(M=50.41$ vs $M=50.32)$, therefore it is completely safe to say that the two groups were quite equivalent in grammatical knowledge on intended grammar points before the treatment. Standard deviation values show that both groups were quite heterogeneous in terms of participants' knowledge. The most frequently occurring scores in the test results of each group are also given in the tables.

Table 3 : Summary for t-test

\begin{tabular}{|c|c|c|}
\hline Test & Control group & Experimental group \\
\hline Pre-test & 50.32 & 50.41 \\
\hline Post-test & 67.86 & 79.95 \\
\hline
\end{tabular}

Source: Developed by the author 
From Table 3 we can see that both groups achieved higher scores in the post-test than in the pre-test. To be more specific, for the control group, the mean score of the post-test was 67.86 compared with 50.32 of the pre-test; and for the experimental group, the mean score of the post-test was 79.95 compared with 50.41 of the pre-test.

To find out whether this difference between the means was statistically significant, a paired-samples t-test was held, as shown in the tables below.

Table 4 : Paired samples statistics

\begin{tabular}{|c|c|c|c|c|}
\hline & Mean & $\mathrm{N}$ & Std. Deviation & $\begin{array}{ll}\text { Std. } & \text { Error } \\
\text { Mean } & \end{array}$ \\
\hline $\begin{array}{l}\text { Pair } 1 \\
\text { Control group } \\
\text { Experimental } \\
\text { group }\end{array}$ & $\begin{array}{l}62.1350 \\
1.5000\end{array}$ & $\begin{array}{l}4 \\
4\end{array}$ & $\begin{array}{l}14.45936 \\
.57735\end{array}$ & $\begin{array}{l}7.22968 \\
.28868\end{array}$ \\
\hline
\end{tabular}

Source: Developed by the author.

Table 5 : Paired samples test

\begin{tabular}{|c|c|c|c|c|c|c|c|c|}
\hline & \multicolumn{5}{|c|}{ Paired Differences } & \multirow[b]{3}{*}{$\mathrm{t}$} & \multirow[b]{3}{*}{$\begin{array}{l}d \\
f\end{array}$} & \multirow{3}{*}{$\begin{array}{l}\text { Sig. } \\
(2- \\
\text { tailed } \\
) \\
\end{array}$} \\
\hline & \multirow[b]{2}{*}{ Mean } & \multirow{2}{*}{$\begin{array}{l}\text { Std. } \\
\text { Deviatio } \\
\mathrm{n}\end{array}$} & \multirow{2}{*}{$\begin{array}{l}\text { Std. } \\
\text { Error } \\
\text { Mean }\end{array}$} & \multicolumn{2}{|c|}{$\begin{array}{l}95 \% \text { Confidence } \\
\text { Interval of the } \\
\text { Difference }\end{array}$} & & & \\
\hline & & & & Lower & Upper & & & \\
\hline $\begin{array}{l}\text { Pair 1 } \\
\text { Control } \\
\text { group } \\
\text { experiment } \\
\text { al group }\end{array}$ & $\begin{array}{l}6.06350 \mathrm{E} \\
1\end{array}$ & $\begin{array}{l}14.3299 \\
2\end{array}$ & $\begin{array}{l}7.1649 \\
6\end{array}$ & $\begin{array}{l}37.8329 \\
0\end{array}$ & $\begin{array}{l}83.4371 \\
0\end{array}$ & $\begin{array}{l}8.46 \\
3\end{array}$ & 3 & .003 \\
\hline
\end{tabular}

Source: Developed by the author.

A confidence interval of the difference was $95 \%$. The results showed that there was a significant difference in the scores for the control group $(\mathrm{M}=62.13, \mathrm{SD}=14.46)$ and experimental group $(\mathrm{M}=1.5, \mathrm{SD}=0.58)$ conditions; $\mathrm{t}=8.5$, $\mathrm{df}=3$, significance $\mathrm{p}=0.003<0.05$, which means that the difference between control and experimental group achievements is statistically significant. Thus, the results of the study displayed that Data-Driven Grammar Learning was an effective grammar teaching method and students of the DDL group achieved significantly higher results than those of the traditional teaching group.

The questionnaire applied to the experimental group of students is shown in Table 6. 
Table 6: Questionnaire for the experimental group students

\begin{tabular}{|l|c|c|c|c|c|}
\hline \multicolumn{1}{|c|}{ Statements } & \multicolumn{3}{|c|}{$\begin{array}{c}\text { 1=Strongly disagree; 2=Disagree; } \\
\text { 3=Neither disagree nor agree; } \\
\text { 4=Agree; 5=Strongly agree }\end{array}$} \\
\hline $\begin{array}{l}\text { 1. The Data-Driven Grammar Learning method was } \\
\text { an interesting and motivational method for learning } \\
\text { English grammar well. }\end{array}$ & 1 & 2 & 3 & 4 & 5 \\
\hline $\begin{array}{l}\text { 2. The Data-Driven Grammar Learning method } \\
\text { transformed the classroom into an active learning } \\
\text { environment. }\end{array}$ & 1 & 2 & 3 & 4 & 5 \\
\hline $\begin{array}{l}\text { 3. Data-Driven Learning of grammar was fun. } \\
\text { 4. Discovering grammatical features on my own was } \\
\text { a more valuable experience than receiving all the } \\
\text { information from my teacher. }\end{array}$ & 1 & 2 & 3 & 4 & 5 \\
\hline $\begin{array}{l}\text { 5. The Data-Driven Grammar Learning method } \\
\text { enhanced classroom interaction (among students, } \\
\text { between the student and the teacher, and the teacher } \\
\text { and the student) }\end{array}$ & 1 & 2 & 3 & 4 & 5 \\
\hline $\begin{array}{l}\text { 6. Exploring the language in authentic contexts was } \\
\text { a meaningful learning experience. }\end{array}$ & 1 & 2 & 3 & 4 & 5 \\
\hline $\begin{array}{l}\text { 7. The Data-Driven Grammar Learning method } \\
\text { generated a skills-based grammar learning process. }\end{array}$ & 1 & 2 & 3 & 4 & 5 \\
\hline $\begin{array}{l}\text { 8. The Data-Driven Grammar Learning method } \\
\text { promoted autonomous learning. }\end{array}$ & 1 & 2 & 3 & 4 & 5 \\
\hline $\begin{array}{l}\text { 9. The inclusion of pair and group work in grammar } \\
\text { teaching boosted my engagement in grammar } \\
\text { learning. }\end{array}$ & & & & & \\
\hline $\begin{array}{l}\text { 10. I would like to continue learning English } \\
\text { grammar through the DDL method. }\end{array}$ & 1 & 2 & 3 & 4 & 5 \\
\hline
\end{tabular}

Source: Developed by the author.

Table 7 shows the statistical analysis of the results for each Likertscale item.

Table 7 : Statistic results of the questionnaire

\begin{tabular}{|c|c|c|c|c|}
\hline & Mean & Median & Mode & Standard Deviation \\
\hline Item 1 & 4.27 & 4 & 4 & 0.63 \\
\hline Item 2 & 4.64 & 4 & 5 & 0.58 \\
\hline Item 3 & 4.04 & 3 & 5 & 1.25 \\
\hline Item 4 & 3.73 & 3 & 4 & 1.28 \\
\hline Item 5 & 4.45 & 3.5 & 5 & 0.8 \\
\hline Item 6 & 3.95 & 3 & 4 & 1.13 \\
\hline Item 7 & 4.5 & 4 & 5 & 0.67 \\
\hline Item 8 & 4.04 & 3 & 4 & 1.04 \\
\hline Item 9 & 4.59 & 4 & 5 & 0.59 \\
\hline Item 10 & 3.95 & 3 & 4 & 1.13 \\
\hline
\end{tabular}

Source: Developed by the author. 
As illustrated, the items of the questionnaire received high results. The lowest mean value was 3.73 and the highest one was 4.64 . The results demonstrated that the students' evaluations of the new method were positive, they turned out to have positive attitudes towards each component of the DataDriven Learning method. The mean to be quite trustworthy has to be close to the median and the mode and in the results of this questionnaire, the mean values were more or less close to the median and mode values. Standard deviation values revealed that the answers to statements $1,2,5,7$, and 9 are relatively homogenous while others are more heterogeneous. The mode values indicate that the answers "Agree" or "Strongly agree" dominated in students" responses.

To be more specific, the questionnaire results revealed that $90.90 \%$ of students found the DDL method as an interesting and motivational grammar learning method. For $95.45 \%$ of students, an active learning environment was created by the DDL method. $81.81 \%$ of students found learning grammar through the DDL method fun. $68.18 \%$ of students valued discovering grammatical features by themselves as a more valuable learning experience than receiving all information from the teacher. $90.90 \%$ of students agreed that the Data-Driven Grammar Learning method enhanced classroom interaction. For $77.27 \%$ of students, the exploration of grammatical features in authentic contexts was a meaningful learning experience. $90.90 \%$ of students accepted that the Data-Driven Learning of grammar was a skills-oriented grammar teaching method. $81.81 \%$ of students approved that the Data-Driven Grammar Learning method promoted autonomous learning. $90.90 \%$ of students agreed that collaborative learning increased their involvement in grammar learning. $77.27 \%$ of students expressed a willingness to continue EFL grammar studying through the Data-Driven Learning method.

To sum up, the findings on research question 1 "How effective is DataDriven Learning of grammar on EFL University students' grammar achievement?" revealed that the Data-Driven Grammar Learning method was more effective than the traditional, deductive grammar teaching approach. The questionnaire results on research question 2 "What are the attitudes of the experimental group students toward the Data-Driven Grammar Learning method?" revealed that the students felt positive towards the Data-Driven Grammar Learning method.

The results of the presented study are in line with the findings of Nugraha, Miftakh, and Wachyudi (2016). The study conducted by Nugraha, Miftakh, and Wachyudi revealed that Indonesian University students had positive attitudes toward the overall Data-Driven Learning method developed by Chujo and Oghigian (2008) and each component of it: DDL worksheet, grammar explanation provided by the teacher, follow-up activities, and feedback from the teacher. 
The results of the introduced study also coincide with the outcomes of Wang (2018). The study conducted by Wang showed that corpus-based grammar teaching had a significantly positive effect on Chinese EFL University students' grammar skills. Class observation and interviews revealed that corpus-based grammar teaching increased students' motivation to learn.

The results of this research are also consistent with the findings of Abdul-Ameer (2019). According to the study conducted by Abdul-Ameer, Iraqi EFL University students showed successful performance on each stage of the Data-Driven Learning model created by Chujo and Oghigian (2008). Students showed satisfaction with the integration of DDL activities in grammar learning and expressed positive attitudes towards each step they underwent.

\section{Conclusion}

This study explored the effect of Data-Driven Learning of grammar on Georgian EFL learners' grammar achievement. The outcomes of the research revealed that Data-Driven Learning was an effective method for the acquisition of grammatical knowledge by the University EFL students. Student questionnaire results showed that students were very positive towards the Data-Driven Grammar Learning method. Based on the findings, it can be concluded that Data-Driven Grammar Learning is an effective grammar teaching method. It revolutionizes the teaching of grammar: promotes the transformation of teacher-centered education to student-centered learning, generates constructivism-based active learning, promotes autonomous learning and increased student engagement, and proposes a skills-oriented, real-language-based grammar learning process. The findings of the present study will bring a new perspective to EFL grammar teaching in Georgia. The study results will encourage EFL teachers to start significant shifts in grammar teaching methodology and move towards student-driven, technologyenhanced authentic learning.

\section{References:}

1. Abdul-Ameer, M. A. (2019). Corpora in the EFL classroom: Exploring the effects of Data Driven Learning (DDL) on Iraqi EFL freshmen's grammatical development. Journal of Basra Researches for Human Sciences, 44(4), 21-33.

2. Al-Gamal, A.A.M., \& Ali, E.A.M. (2019). Corpus-based method in language learning and teaching. International Journal of Research and Analytical Reviews (IJRAR), 6(2), 473-476.

3. Boulton, A. (2008). Looking (for) empirical evidence of data-driven learning at lower levels. In B. Lewandowska-Tomaszczyk (Ed.), 
Corpus Linguistics, Computer Tools, and Applications: State of the Art (volume 17) (pp. 581-598). Frankfurt: Peter Lang.

4. Boulton, A., \& Cobb, T. (2017). Corpus use in language learning: A meta-analysis. Language Learning, 67(2), 348-393.

5. Brown, M.H. (2017). Using the sentence corpus of remedial English to introduce Data-Driven Learning tasks. Kanda Academic Review, 1(1), 1-14.

6. Chambers, A. (2010). What is data-driven learning. In A. O'Keeffe \& M. McCarthy (Eds.) The Routledge Handbook of Corpus Linguistics (pp. 345-358). New York: Routledge.

7. Chujo, K., \& Oghigian, K. (2008). A DDL approach to learning noun and verb phrases in the beginner level EFL classroom. In Proceedings of 8th Teaching and Language Corpora (TaLC) Conference (pp. 6571). Lisbon, Portugal: ISLA Lisboa.

8. Chujo, K., Utiyama, M., \& Miura, S. (2006). Using a Japanese-English parallel corpus for teaching English vocabulary to beginning-level students. English Corpus Studies, 13, 153-172.

9. Elsherbini, S.A.H., \& Ali, A.D. (2017). The Effects of corpus-based activities on EFL University students' grammar and vocabulary and their attitudes toward corpus. Journal of Research in Curriculum Instruction and Educational Technology, 3(1), 133-161.

10. Flowerdew, L. (2009). Applying corpus linguistics to pedagogy: A critical evaluation. International Journal of Corpus Linguistics, 14(3), 393-417.

11. Hardie, A. (2012). CQPweb - combining power, flexibility, and usability in a corpus analysis tool. International Journal of Corpus Linguistics, 17(3), 380-409. Available at https://cqpweb.lancs.ac.uk/.

12. Huang, L.S. (2008). Using guided, corpus-aided discovery to generate active learning. English Teaching Forum, 46(4), 20-27.

13. Huang, L.S. (2018). Corpus-based instruction. The TESOL Encyclopedia of English Language Teaching, 1, 1-11.

14. Johns, T. (1990). From printout to handout: Grammar and vocabulary teaching in the context of data-driven learning. CALL Austria, 10, 1434.

15. Kazuko (2014). Using a corpus in an EFL classroom to develop depth of vocabulary knowledge. The Tsuru University Revirew, 79, 133-146.

16. Lee, H.C. (2011). In defense of concordancing: An application of datadriven learning in Taiwan. Procedia-Social and Behavioral Sciences, 12, 399-408.

17. Lili, Z. (2015). The application of corpus in English writing and its influences. Studies in Sociology of Science, 6(6), 78-82. 
18. Mann, M., \& Taylore-Knowles, S. (2013). LASER BI (second edition). London: Macmillan Education.

19. Meunier, F. (2002). The pedagogical value of native and learner corpora in EFL grammar teaching. In S. Granger, J. Hung \& S. PetchTyson (Eds.) Computer Learner Corpora, Second Language Acquisition and Foreign Language Teaching (Vol. 6) (pp. 119-142). Amsterdam: John Benjamins Publishing.

20. Nugraha, S.I., Miftakh, F., \& Wachyudi, K. (2016). Teaching grammar through data-driven learning (DDL) approach. Advances in Social Science, Education and Humanities Research (ASSEHR), 82, 300-303.

21. O'Keeffe, A., McCarthy, M., \& Carter, R. (2007). From corpus to classroom: language use and language teaching. Cambridge: Cambridge University Press.

22. O'Sullivan, I. (2007). Enhancing a process-oriented approach to literacy and language learning: The role of corpus consultation literacy. ReCALL: The Journal of EUROCALL, 19(3), 269-286.

23. Reppen, R. (2010). Using corpora in the language classroom. Cambridge: Cambridge University Press.

24. Sah, P.K. (2015). Using Data-Driven Learning (DDL) to enhance learner autonomy. IATEFL SIG Independent, 64, 12-15.

25. Takahashi, S., \& Fujiwara, Y. (2016). Effects of inductive learning based on Data-Driven Learning at elementary schools in Japan. JES Journal, 16(1), 84-99.

26. Wang, X. (2018). Effect of a corpus-based grammar teaching method in the Chinese EFL environment. Advances in Social Science, Education and Humanities Research (ASSEHR), 182, 294-297.

27. Yunus, K. (2014). The impact of Data-Driven Learning instruction on Malaysian law undergraduates' colligational competence. Kajian Malaysia, 32(1), 79-109.

28. Zhang, Y., \& Liu, L. (2014). A corpus-aided approach in EFL instruction: A case study of Chinese EFL learners' use of the infinitive. English Language Teaching, 7(7), 152-158. 